\title{
Article
}

\section{Prevalence and Risk Factors of Respiratory Syncytial Virus in Children under 5 Years of Age in the WHO European Region: A Systematic Review and Meta-Analysis}

\author{
Nora Suleiman-Martos ${ }^{1}{ }^{(\mathbb{D}}$, Alberto Caballero-Vázquez ${ }^{2}$, Jose Luis Gómez-Urquiza ${ }^{3}{ }^{\mathbb{C}}$, Luis Albendín-García ${ }^{4}{ }^{\mathbb{D}}$, \\ Jose Luis Romero-Béjar ${ }^{5, *(1)}$ and Guillermo A. Cañadas-De la Fuente ${ }^{3(1)}$ \\ 1 Faculty of Health Sciencies, University of Granada, Cortadura del Valle S/N, 51001 Ceuta, Spain; \\ norasm@ugr.es \\ 2 Diagnostic Lung Cancer Unit, Broncopleural Techniques and Interventional Pulmonology Department, \\ Hospital Universitario Virgen de las Nieves, 18014 Granada, Spain; \\ alberto.caballero.sspa@juntadeandalucia.es \\ 3 Faculty of Health Sciencies, University of Granada, Avenida Ilustración, 60, 18016 Granada, Spain; \\ jlgurquiza@ugr.es (J.L.G.-U.); gacf@ugr.es (G.A.C.-D.l.F.) \\ 4 Granada-Metropolitan District, Andalusian Health Service, Avenida del Sur, 11, 18014 Granada, Spain; \\ lualbgar1979@ugr.es \\ 5 Department of Statistics and Operational Research, University of Granada. Av. Fuentenueva, \\ 18071 Granada, Spain \\ Citation: Suleiman-Martos, N.;

Caballero-Vázquez, A.;

Gómez-Urquiza, J.L.;

Albendín-García, L.; Romero-Béjar,

J.L.; Cañadas-De la Fuente, G.A.

Prevalence and Risk Factors of

Respiratory Syncytial Virus in

Children under 5 Years of Age in the WHO European Region: A Systematic Review and Meta-Analysis. J. Pers. Med. 2021, 11, 416. https://doi.org/ 10.3390/jpm11050416

Academic Editor: Soterios

A. Kyrtopoulos

Received: 5 April 2021

Accepted: 13 May 2021

Published: 15 May 2021

Publisher's Note: MDPI stays neutral with regard to jurisdictional claims in published maps and institutional affiliations.

\begin{abstract}
A respiratory syncytial virus (RSV) is the major cause of respiratory tract infection in children under 5 years. However, RSV infection in the European Region of the World Health Organization has not been systematically reviewed. The aim was to determine the prevalence and factors associated with RSV in children under 5 years of age in European regions. A systematic review and meta-analysis was performed. CINAHL, Medline, LILACS, ProQuest, SciELO, and Scopus databases were consulted for studies published in the last 5 years, following Preferred Reporting Items for Systematic Reviews and Meta-analysis guidelines. The search equation was "respiratory syncytial virus AND (newborn OR infant OR child) AND (prevalence OR risk factors)". Studies reporting the prevalence of RSV were eligible for inclusion in the meta-analysis. A total of 20 articles were included. The meta-analytic prevalence estimation of RSV, with a sample of $\mathrm{n}=16,115$ children, was $46 \%$ (95\% CI 34-59\%). The main risk factors were age, male gender, winter season, and environmental factors such as cold temperatures, higher relative humidity, high concentrations of benzene, exposure to tobacco, and living in urban areas. Robust age-specific estimates of RSV infection in healthy children should be promoted in order to determine the optimal age for immunization. In addition, it is necessary to analyse in greater depth the potentially predictive factors of RSV infection, to be included in prevention strategies.
\end{abstract}

Keywords: respiratory syncytial virus; risk factors; prevalence; children; epidemiology; metaanalysis

\section{Introduction}

Respiratory syncytial virus (RSV) is a single-stranded RNA virus that belongs to the Paramyxoviridae family, affecting respiratory epithelial cells and presenting two subtypes, RSV A (the most severe form of presentation) and RSV B [1].

It is one of the main causes of acute lower respiratory tract infection (ALRI), particularly in children under one year of age [2]. Worldwide, it is estimated that there are 33 million cases of ALRI per year associated with RSV in children under 5 years of age [3] of which 3.2 million cases require hospitalization [4]. In addition, RSV is one of the main 
causes of mortality with about 60 thousand deaths per year throughout the world in children under 5 years of age [5].

RSV is characterized by being seasonal, whose infection rate peaks in the cold season in temperate climates [6]. Primary infection from 6 months to 2 years is usually symptomatic, with around $40 \%$ of infections presenting bronchiolitis and pneumonia. The incubation period of the infection ranges from 3 to 5 days, and the clinical presentation of RSV can vary according to age, with the most common symptoms being rhinorrhoea, nasal congestion, cough, fever or respiratory distress [7]. Up to $40 \%$ of infants progress to ALRI with coughing and wheezing, which range in severity from mild to moderate illness to life-threatening respiratory failure [8]. In addition, the consequences can be negative, especially in children with underlying diseases (prematurity, lung disease, congenital heart disease, congenital or acquired immunodeficiency, or Down syndrome) [9-11].

Currently, the drug of choice as prophylaxis to prevent RSV infection is palivizumab, being recommended for high-risk population [12]. However, the high rate of hospitalization and mortality has produced a growing interest in new vaccines and therapies against RSV, in order to include a larger target population such as infants, pregnant women, or the elderly population $[13,14]$. In the past decade, 10 vaccines and 11 therapeutic agents in active clinical trials have been developed, noting that maternal vaccination is particularly relevant [13]. New treatments have also been developed such as Ribavirin, although not routinely recommended in light of limited evidence of benefit [15]. Nevertheless, the treatment and prophylaxis options are still limited.

In 2015, the World Health Organization (WHO) indicated a high priority on establishing global RSV disease surveillance systems, as well as robust age-specific estimations in order to determine the optimal age for immunization [16]. However, data on the prevalence of RSV and the burden of disease in healthy children are scarce, as most studies are conducted only in high-risk groups [17-19].

Specifically, in Europe, there are few studies on RSV infection. Some studies have investigated the seasonality and geography of RSV in European countries [20]. However, to date, there is no systematic review that evaluates the prevalence and risk factors of RSV in healthy children in the WHO European Region. Therefore, and in order to obtain a better understanding of the severity of RSV infection, the objective of this systematic review and meta-analysis is to analyse the prevalence and risk factors of RSV infection in children under 5 years of age.

\section{Materials and Methods}

A systematic review was performed following PRISMA statement (Preferred Reporting Items for Systematic Reviews and Meta-analyses) [21].

\subsection{Data Sources and Search Strategy}

CINAHL, Medline, LILACS, ProQuest, SciELO and Scopus databases were consulted. The search was done in December 2020, using MeSH descriptors and with the following search equation: "respiratory syncytial virus AND (newborn OR infant OR child) AND (prevalence OR risk factors)".

\subsection{Study Selection Process}

Two authors independently analysed the title and abstract of the articles found, eliminating duplicate studies. Subsequently, the full-texts were reviewed, evaluating them according to inclusion criteria. In case of disagreement, a third author was consulted.

\subsection{Inclusion and Exclusion Criteria}

The inclusion criteria were the following: (1) countries included in the WHO European Region; (2) published in English, French, Spanish, Portuguese, and Italian; (3) published in the last 5 years; (4) children under 5 years of age; (5) gestational age greater than 37 weeks; (6) diagnosis of acute respiratory tract infection (respiratory infection, pneumonia, or 
bronchiolitis); (7) RSV diagnosis confirmed by laboratory tests; (8) prevalence measurement showing RSV infection positive rate outcome data or providing enough information to calculate the effect size (number of RSV infected patients and total number of patients); and (9) RSV-associated factors.

Articles that did not meet the following criteria were excluded: (1) without a clear diagnosis of RSV, (2) studies that included a high-risk population (with a diagnosis of chronic lung disease, bronchopulmonary dysplasia, cystic fibrosis, or premature infants), (3) with prior prophylaxis (palivizumab or other prevention strategies for RSV infection), and (4) case definition that was not clearly defined.

We did not include studies published before 2015 because seasonality could change and our objective was to report on current global seasonality. There were no restrictions on the healthcare setting or definition of RSV infection.

\subsection{Data Extraction}

Two authors extracted data from all included studies using a data coding form. A third author checked the data for disagreement. The following variables were obtained for each of the articles: (1) author, year of publication, and country; (2) design and study period; (3) age; (4) diagnostic procedure used; (5) sample; (6) place of detection of the case; (7) prevalence; and (8) risk factors.

To assess the reliability of the data coding by the researchers, the intraclass correlation coefficient was calculated as 0.98 (minimum $=0.97$; maximum $=1)$. Cohen's Kappa coefficient used for categorical variables was $0.97($ minimum $=0.96$; maximum $=1)$.

\subsection{Quality Evaluation and Risk Bias}

In order to assess the quality of the studies included in the review, the levels of evidence and grades of recommendation of the Oxford Center for Evidence-based Medicine (OCEBM) were followed [22], as well as the STROBE (Strengthening the Reporting of Observational Studies in Epidemiology) guide [23].

\subsection{Data Analysis}

A random effects meta-analysis was performed to calculate the prevalence of RSV and the corresponding confidence interval. The software used was StatsDirect (StatsDirect Ltd., Cambridge, UK), presenting the results grouped in a forest plot.

Analysis of heterogeneity was performed by measuring $\mathrm{I}^{2}$. There was significant heterogeneity if the $\mathrm{I}^{2}$ values were greater than 50\% [24]. Publication bias was assessed using Egger's linear regression test and also a sensitivity analysis was performed.

\section{Results}

The initial search strategy identified 2823 references. After reading the title and abstract, 1153 were eliminated. After reading the full text, a total of 177 articles were eliminated. The selection of articles is reflected in Figure 1. 

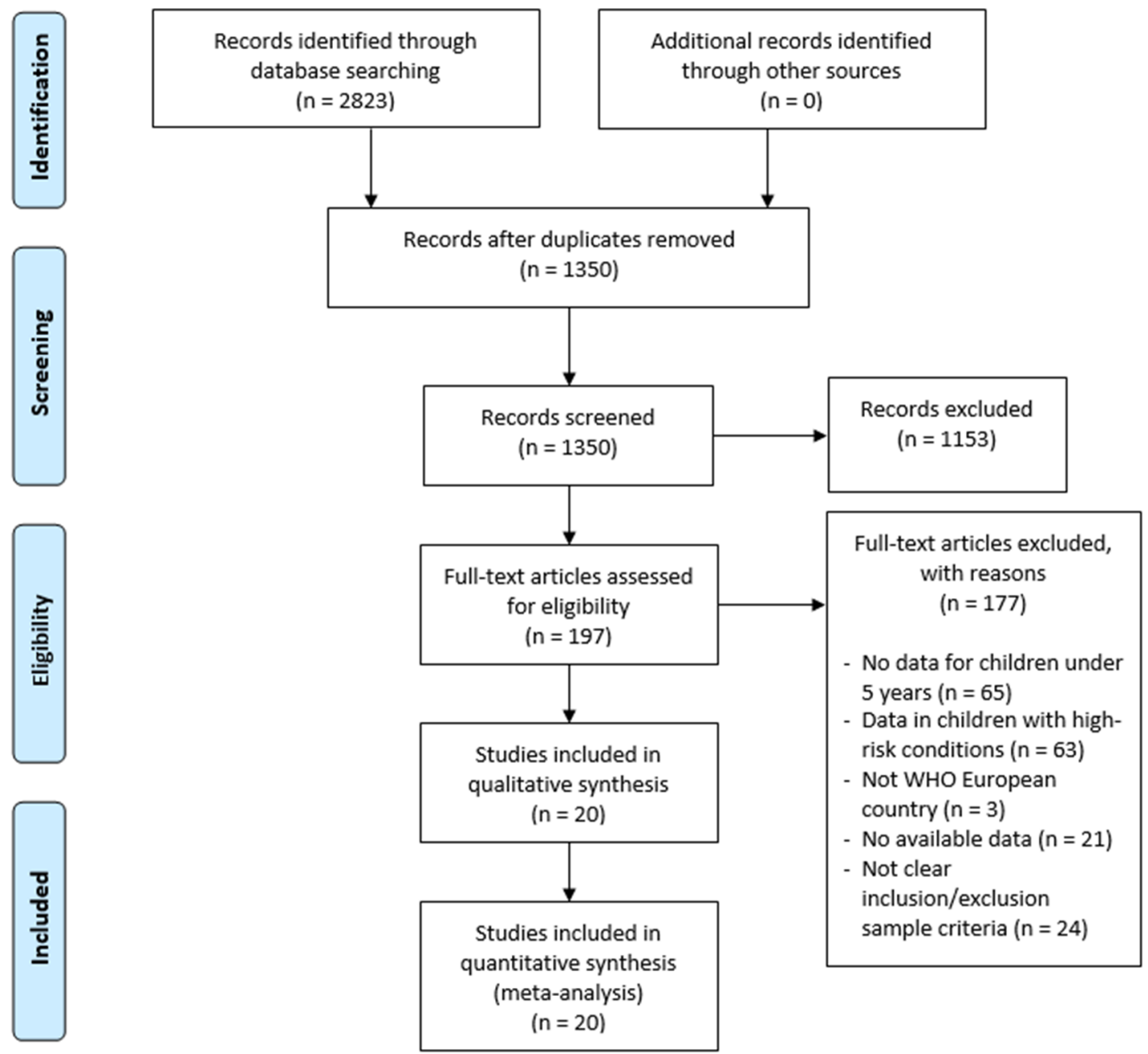

Figure 1. Flow diagram of the selection process.

\subsection{Characteristics of Included Studies}

The sample consisted of a total of $n=16,115$ children. Most of the studies were cohort studies $(75 \%)$, followed by cross-sectional studies $(20 \%)$ and cases and controls $(5 \%)$. Most of the studies were conducted in Italy $(n=6)$, followed by the Netherlands $(n=3)$ and Bulgaria $(n=3)$. Regarding methodological quality, all studies had an adequate level of quality. The evaluation and characteristics of the studies are represented in Table 1. 
Table 1. Characteristic of included studies $(n=20)$.

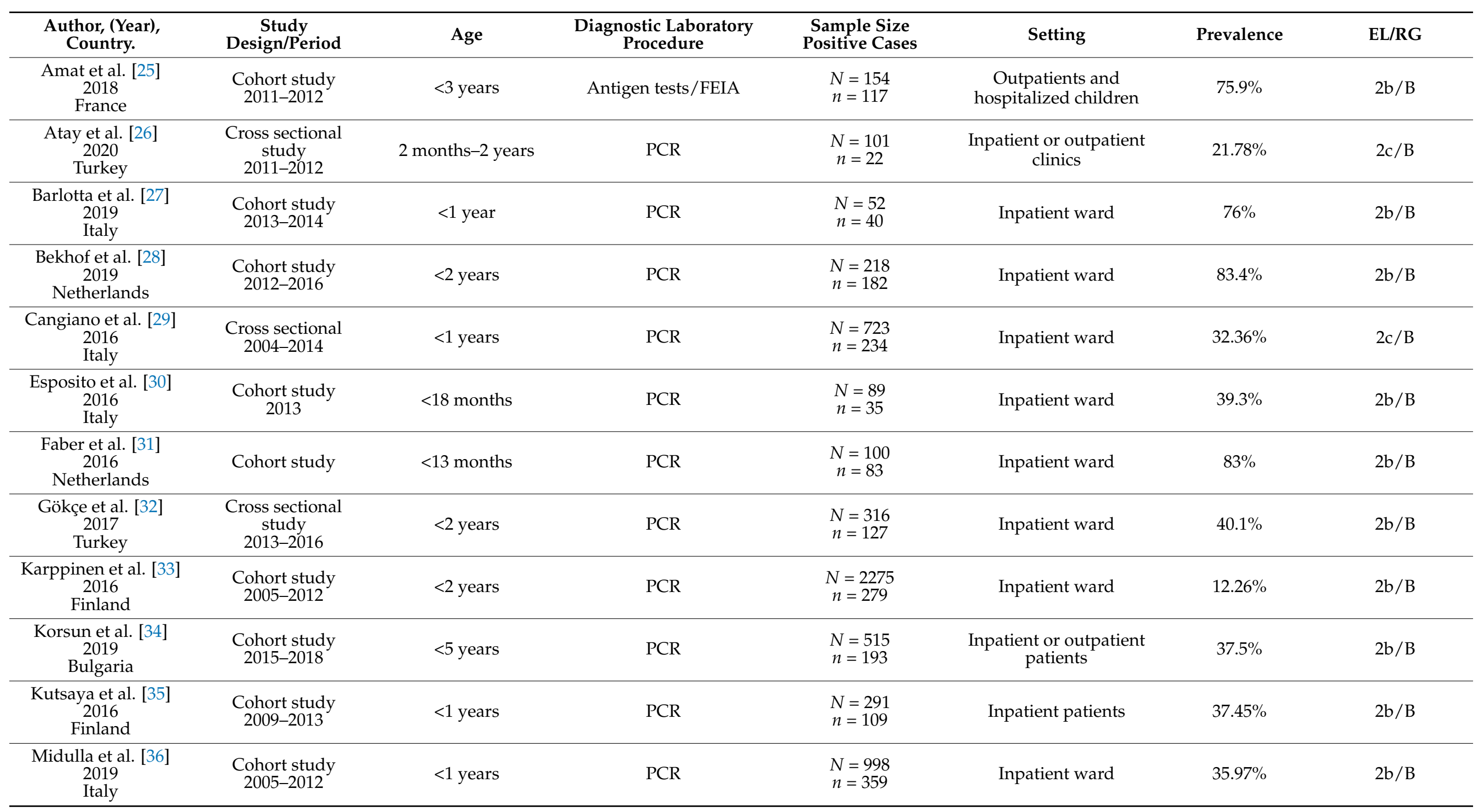


Table 1. Cont.

\begin{tabular}{|c|c|c|c|c|c|c|c|}
\hline $\begin{array}{l}\text { Author, (Year), } \\
\text { Country. }\end{array}$ & $\begin{array}{c}\text { Study } \\
\text { Design/Period }\end{array}$ & Age & $\begin{array}{c}\text { Diagnostic Laboratory } \\
\text { Procedure }\end{array}$ & $\begin{array}{l}\text { Sample Size } \\
\text { Positive Cases }\end{array}$ & Setting & Prevalence & EL/RG \\
\hline $\begin{array}{c}\text { Nenna et al. [37] } \\
2017 \\
\text { Italy }\end{array}$ & $\begin{array}{l}\text { Cohort study } \\
\text { 2004-2014 }\end{array}$ & $<1$ years & PCR & $\begin{array}{l}N=723 \\
n=266\end{array}$ & Inpatient ward & $36.79 \%$ & $2 b / B$ \\
\hline $\begin{array}{c}\text { Petrarca et al. [38] } \\
2018 \\
\text { Italy }\end{array}$ & $\begin{array}{l}\text { Cross sectional } \\
\text { 2004-2016 }\end{array}$ & $<1$ years & PCR & $\begin{array}{l}N=486 \\
n=365\end{array}$ & Inpatient ward & $75.1 \%$ & $2 b / B$ \\
\hline $\begin{array}{c}\text { Ramos-Fernández } \\
\text { et al. [39] } \\
2017 \\
\text { Spain }\end{array}$ & $\begin{array}{l}\text { Case-control } \\
\text { study2010-2015 }\end{array}$ & $<6$ months & Antigen tests & $\begin{array}{c}N=1006 \\
n=695\end{array}$ & Inpatient ward & $69 \%$ & $1 \mathrm{~b} / \mathrm{A}$ \\
\hline $\begin{array}{c}\text { Resch et al. [40] } \\
2019 \\
\text { Austria }\end{array}$ & $\begin{array}{l}\text { Cohort study } \\
\text { 2005-2015 }\end{array}$ & 39-42 weeks & PCR & $\begin{array}{c}N=136 \\
n=23\end{array}$ & Inpatient ward & $16.9 \%$ & $2 b / B$ \\
\hline $\begin{array}{c}\text { Shmueli et al. [41] } \\
2017 \\
\text { Israel }\end{array}$ & $\begin{array}{l}\text { Cohort study } \\
\text { 2012-2013 }\end{array}$ & $<2$ years & Antigen tests/FEIA & $\begin{array}{l}N=286 \\
n=203\end{array}$ & Inpatient ward & $70.9 \%$ & $2 b / B$ \\
\hline $\begin{array}{c}\text { Toivonen et al. [42] } \\
2020 \\
\text { Finland }\end{array}$ & $\begin{array}{l}\text { Cohort study } \\
\text { 2008-2010 }\end{array}$ & $<2$ years & Antigen tests/PCR & $\begin{array}{c}N=4728 \\
n=289\end{array}$ & $\begin{array}{l}\text { Inpatient or outpatient } \\
\text { clinics }\end{array}$ & $6 \%$ & $2 b / B$ \\
\hline
\end{tabular}

\begin{tabular}{|c|c|c|c|c|c|c|c|}
\hline $\begin{array}{l}\text { Van de Steen et al. } \\
\qquad[43] \\
2016 \\
\text { Central and Eastern } \\
\text { Europe countries }^{1}\end{array}$ & $\begin{array}{l}\text { Cohort study } \\
\text { 2009-2011 }\end{array}$ & $<1$ years & Antigen tests & $\begin{array}{l}N=2677 \\
n=1034\end{array}$ & Inpatient ward & $38.62 \%$ & $2 \mathrm{~b} / \mathrm{B}$ \\
\hline $\begin{array}{c}\text { Wishaupt et al. [44] } \\
2016 \\
\text { Netherlands }\end{array}$ & $\begin{array}{l}\text { Cohort study } \\
\text { 2011-2014 }\end{array}$ & $<3$ months & PCR & $\begin{array}{c}N=241 \\
n=108\end{array}$ & Inpatient ward & $40.14 \%$ & $2 b / B$ \\
\hline
\end{tabular}

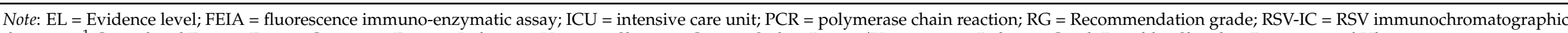
detection. ${ }^{1}$ Central and Eastern Europe Countries: Estonia, Lithuania, Hungary, Slovenia, Croatia, Serbia, Bosnia/Herzegovina, Bulgaria, Czech Republic, Slovakia, Romania, and Ukraine. 


\subsection{Risk Factor (Age)}

The hospitalization rate presents an inversely proportional relationship to age, reaching a maximum in the first months of life $[29,36]$. For some, in the first 6 months, there is a greater RSV infection [32,34], although other authors find that the frequency of RSVpositives increases after 5 months of age compared to those from 0 to 4 months [30]. However, for other authors, the highest number of cases is between the first and third year of life [35,42]. See Table 2.

Table 2. Main risk factors associated with RSV infection.

\begin{tabular}{|c|c|}
\hline Author, (year) & Risk Factors \\
\hline Atay et al. [26], 2020 & $\begin{array}{l}\text { Male gender (OR 1.73, 95\% CI 1.0-5.7\%, } p=0.302) \\
\text { Crowded household population (OR } 1.73,95 \% \text { CI } 1.0-5.7 \%, p=0.046) \\
\text { Heating stoves (OR 0.31, 95\% CI } 0.1-0.98 \%, p=0.025) \\
\text { Urban cities }(p<0.001) \\
\text { Exposure to smoking }(p=0.001) \\
\text { Peak February }\end{array}$ \\
\hline Cangiano et al. [29], 2016 & $\begin{array}{l}\text { Younger }(p<0.001) \\
\text { Peak December-February } \\
\text { Maternal smoke during pregnancy }(p=0.036)\end{array}$ \\
\hline Esposito et al. [30], 2016 & $\begin{array}{l}\text { Age (OR 6.3, 95\% CI } 1.4-33.9 \%, p=0.02) \\
\text { Age } \geq 5 \text { months old (children 5-8 months old and 9-16 months old vs. } \\
\text { children } \\
0-4 \text { months old: } p=0.03 \text { and } p=0.003 \text {, respectively) } \\
\text { Attended day care }(p=0.001) \\
\text { Birth date (OR } 2.7,95 \% \text { CI } 1.1-6.7 \%, p=0.03 \text { ) } \\
\text { Male gender (OR } 2.3,95 \% \text { CI } 1.0-5.7 \%, p=0.06)\end{array}$ \\
\hline Gökçe et al. [32], 2017 & $\begin{array}{l}\text { Peak January-March } \\
\text { Younger }(<6 \text { months })\end{array}$ \\
\hline Karppinen et al. [33], 2016 & $\begin{array}{l}\text { Male (OR } 1.06,95 \% \text { CI } 0.57-1.99 \%, p=0.85) \\
\text { Socioeconomic status (OR 0.78, 95\% CI } 0.39-1.56 \%, p=0.48 \text { ) }\end{array}$ \\
\hline Korsun et al. [34], 2019 & $\begin{array}{l}\text { Youngest age group: }<6 \text { months }(50 \%) \text {, followed by } 6-11 \text { months }(38.5 \%) \\
\text { Of the RSV-positive children } 58.5 \% \text { were under } 2 \text { years of age: } 61 \% \text { were } \\
\text { boys and } 39 \% \text { were girls }(p=0.5773)\end{array}$ \\
\hline Kutsaya et al. [35], 2016 & $\begin{array}{l}\text { RSV seroprevalence increased from } 37 \% \text { at age } 1 \text { year to } 68 \% \text { at age } 2 \text { years, } \\
\text { and to } 86 \% \text { at age } 3 \text { years }\end{array}$ \\
\hline Midulla et al. [36], 2019 & $\begin{array}{l}\text { Younger }(p<0.0001) \\
\text { Lower body weight at admission }(p=0.005) \\
\text { Born in winter }\end{array}$ \\
\hline Nenna et al. [37], 2017 & $\begin{array}{l}\text { The number of RSV-positive infants correlated negatively with cold } \\
\text { temperature }(\mathrm{r}=-0.46, p<0.001) \text {, and positively with higher relative } \\
\text { humidity }(\mathrm{r}=0.36, p<0.001) \\
\text { Peak December-February }\end{array}$ \\
\hline Petrarca et al. [38], 2018 & No relation to exposure to smoke, breastfeeding, birth weight and sex \\
\hline Ramos-Fernández et al. [39], 2017 & $\begin{array}{l}\text { Male (OR 4.27, 95\% CI 1.14-15.93\%, } p=0.03 \text { ) } \\
\text { Low birth weight (<3rd percentile) (OR 5.53, 95\% CI } 0.93-32.97 \%, p=0.06 \text { ) }\end{array}$ \\
\hline Resch et al. [40], 2019 & $\begin{array}{l}\text { No relation to smoking during pregnancy } \\
\text { Peak January }\end{array}$ \\
\hline Toivonen et al. [42], 2020 & $\begin{array}{l}\text { Of all RSV infections, } 10 \% \text { occurred before } 3 \text { months of age, } 16 \% \text { at } 3-5 \\
\text { months of age, } 32 \% \text { at } 6-11 \text { months of age, and } 42 \% \text { at } 12-24 \text { months of age } \\
\text { Peak February-May }\end{array}$ \\
\hline Van de Steen et al. [43], 2016 & Duration of hospitalization $(p<0.001)$ \\
\hline
\end{tabular}

\subsection{Risk Factor (Gender and Weight at Birth)}

Regarding gender, there is a relationship between male gender and RSV infection, presenting a higher percentage of infection $[30,33,34,39]$, although other authors do not find any relationship [38].

Low birth weight is also considered a risk factor [36] and more specifically if it is below the third percentile [39], although other authors find no relationship [38,40].

\subsection{Risk Factor (Seasonality)}

The seasonal distribution of RSV reaches its maximum peak during the winter season, for some during the months of January-February [26,40], December-February [29,37,38], January-March [32], and February-May [42]. 


\subsection{Environmental Risk Factors}

A negative correlation is found between cold temperatures and the number of RSV positive children as well as the number of hospitalizations [37]; and a positive correlation if there is a higher relative humidity [37]. The spikes of contagion by RSV are also related to certain atmospheric pollutants such as benzene [37].

The environmental home conditions, such as the use of heating with stoves, are related to the number of cases of RSV infection, finding that these children present more serious episodes. In addition, exposure to tobacco is also considered a risk factor $[26,29,40]$.

\subsection{Another Risk Factors}

In relation to the place of residence, there is an increase in the number of RSV hospitalizations in children living in urban areas and in the crowded household population [26]. Those children who attend kindergarten [30] have a higher rate of RSV infection. Moreover, the risk increases the longer the length of hospital stay [43].

\subsection{Meta-Analysis Prevalence Estimation}

The sample of the meta-analysis was $\mathrm{n}=16,115$ children. The meta-analytical estimation of RSV was $46 \%$ (95\% CI 34-59\%). The $\mathrm{I}^{2}$ value was $99.4 \%$ indicating a high heterogeneity. Egger test did not show publication bias and no study was removed after the sensitivity analysis. The forest plot is shown in Figure 2.

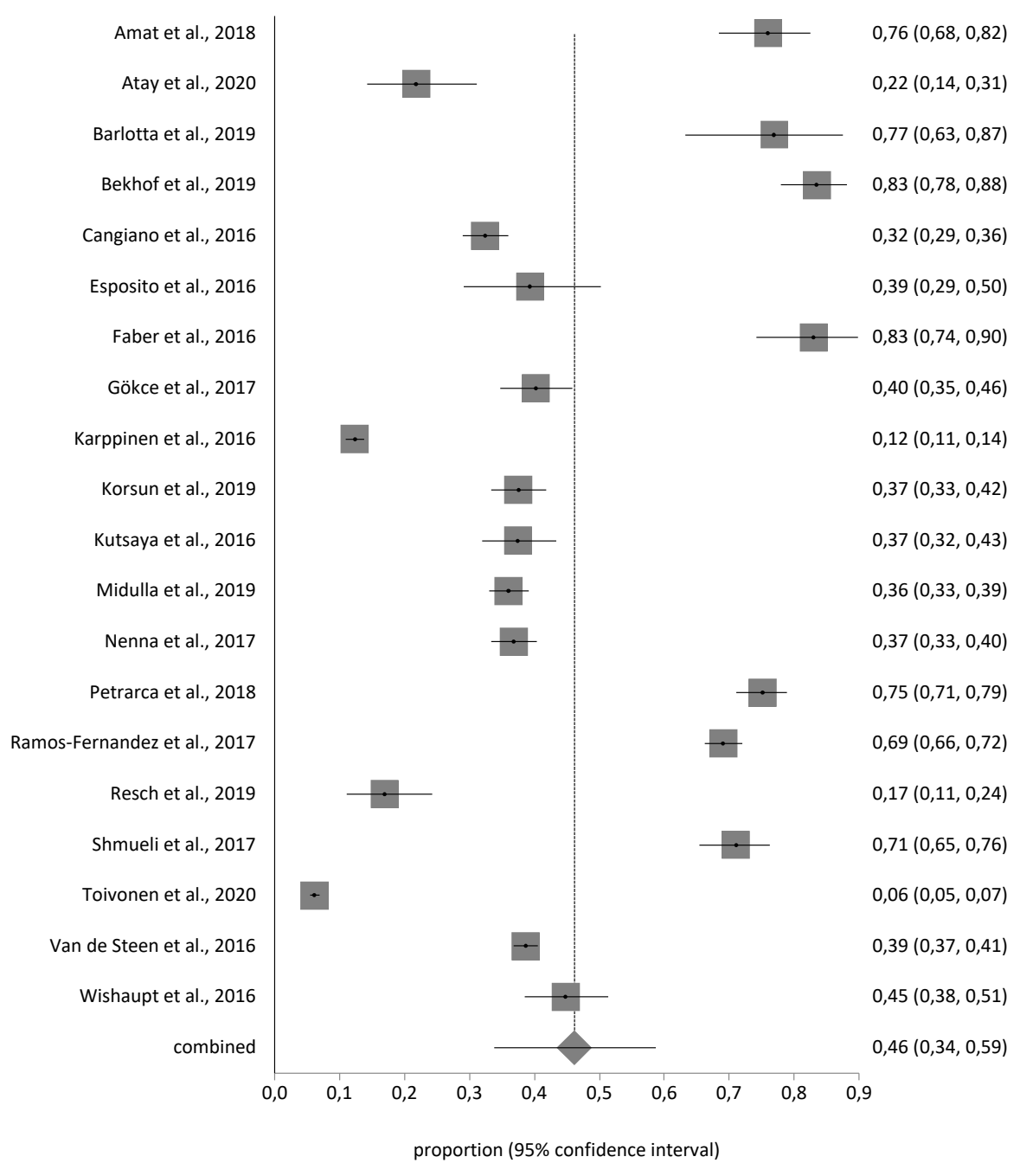

Figure 2. Forest plot of RSV prevalence. 


\section{Discussion}

The prevalence of RSV infection in children from WHO European countries was $46 \%$ (95\% CI 34-59\%). This percentage is similar to that of other continents such as Latin America, with an RSV prevalence of 41.5\% (95\% CI 32-51.4\%) [45]. Other authors find a global positive rate of RSV infection lower than that of this study, as is the case in Africa with a prevalence of $14.6 \%$ (95\% CI 13-16.4\%) [46] or China with $16 \%$ (95\% CI 12.9-19.6\%) [47]. Even studies carried out in European countries such as France find a lower prevalence of positive RSV of 12-18\% [48] and in the US the percentages of RSV infection in healthy children are only $1.8 \%$ [49].

Regarding age, we found that RSV infection was detected more frequently in children up to 3 years of age. These results are similar to those of other studies that confirm a significantly higher rate in children under 3 years of age (19.5\%) compared to children over 3 years of age (5.6\%) [47]. Even multicenter studies find that in children under 6 months the prevalence is $50 \%$ and in children under 2 years of age $88 \%$, a fact that corroborates the high burden of RSV in children $<2$ years, especially in infants $<6$ months $[50,51]$. The younger the age, the greater the risk of RSV infection, as corroborated by several authors, indicating a greater risk especially in children between 3 to 5 months [48,52,53], although other studies point out that RSV-associated hospitalizations reach their maximum peak in children under 3 months [54]. Other authors suggest a higher percentage of infection in children 0 to 12 months of age [45,54-58].

Gender influences RSV infection, boys have a higher risk of severe RSV infection compared to girls [48,59]. Some studies that have investigated these differences in greater depth indicate an infection ratio of two boys for every girl, the difference in the sex ratio being the highest in the first months of life [59].

Episodes of infection usually occur between November and March, with a peak in January-February [51]. Even some studies when analysing the percentage of RSV infection and its relationship with the month of birth, find a low prevalence for children born in April of 5.7\%, being higher in children born in November, of 49.6\% [60].

Climatic factors also contribute to promoting RSV infection. Like our results, many studies have highlighted that colder temperatures during the months with the highest RSV prevalence are associated with a greater probability of hospitalization for RSV [51,57]. Furthermore, the positivity of RSV is also higher in environmental conditions of high relative humidity, high atmospheric pressure and even wind speed [51,61].

Other authors, as in this study, consider the importance of exposure to tobacco smoke as a risk factor for RSV infection, aggravating the severity of bronchiolitis or the risk of other acute lower respiratory tract infections [62], although others do not find this association [51,63].

RSV positivity is higher in children with characteristics such as low socioeconomic status and the length of the children's hospital stay also has a negative influence [51]. In this review, we did not find a relationship between maternal aspects and RSV infection, while other studies indicate a short duration of breastfeeding as a risk factor as well as being born by spontaneous vaginal delivery [51].

The high rate of RSV infection and its negative consequences for the health of children makes it necessary to analyse the existing prevalence, as well as the associated risk factors to prioritize and early identify children at high risk of developing infection associated with RSV [64]. However, most of the research is focused on analysing RSV-associated infection without providing data on its classification according to age.

Hospital admissions for respiratory infections due to RSV remain a significant health problem among young children. However, underreporting, misclassification, and lack of national guidelines regarding RSV diagnostic testing indicate that statistics are rarely sufficient to estimate the incidence or prevalence of RSV-associated disease, which implies more studies in order to know real data [64]. Furthermore, few studies have been conducted to assess the burden of RSV infection in healthy children. A global report of the monthly 
activity of these viruses is needed to develop public health strategies and programs for their control.

Further efforts are needed to find new strategies to reduce the RSV. Thus, developing measures in order to reduce children's exposure to indoor and outdoor pollution and identifying additional environmental factors, would contribute to reducing RSV hospitalization and morbidity and mortality.

\section{Limitations}

First, the number of studies is low because not all studies reported the prevalence of RSV or its risk factors. Furthermore, many studies contemplated different respiratory diseases in the global population without analysing the different age groups. Second, the analysis of risk factors has been performed individually, lacking multivariate analysis.

Finally, although the inclusion criteria were established to find studies with similar populations, there was high heterogeneity between the studies. It can be explained by the diversity of countries, where the health-seeking behaviour of populations is likely to vary depending on different cultural contexts.

\section{Conclusions}

To our knowledge, this is the first meta-analysis to address the prevalence of RSV infection and associated factors in children under 5 years of age in the WHO European Regions. A 46\% prevalence of RSV was observed. Among the main risk factors are age, male gender, winter season, and environmental factors such as cold temperatures, higher relative humidity, high concentrations of benzene, exposure to tobacco, and living in urban areas. All of them are potentially predictive factors to prevent the development of RSV infection and, therefore, should be taken into account when establishing prevention strategies. RSV infection in children, as the most vulnerable group, deserves more research, particularly at promoting the provision of a vaccine for this population group.

Author Contributions: N.S.-M.: Conceptualization, formal analysis, investigation, data processing and validation, writing-original draft preparation; A.C.-V.: resources, investigation, visualization, supervision; L.A.-G.: formal analysis, investigation, writing —original draft preparation; J.L.G.-U.: methodology, software, resources, writing-review and editing; J.L.R.-B.: software, data processing and validation, writing - review and editing; G.A.C.-D.1.F.: conceptualization, methodology, visualization, supervision. All authors have read and agreed to the published version of the manuscript.

Funding: This research received no external funding.

Institutional Review Board Statement: Not applicable.

Informed Consent Statement: Not applicable.

Data Availability Statement: Data available in request to correspondence author.

Conflicts of Interest: The authors declare no conflict of interest.

\section{References}

1. Pellegrinelli, L.; Galli, C.; Bubba, L.; Cereda, D.; Anselmi, G.; Binda, S.; Gramegna, M.; Pariani, E. Respiratory syncytial virus in influenza-like illness cases: Epidemiology and molecular analyses of four consecutive winter seasons (2014-2015/2017-2018) in Lombardy (Northern Italy). J. Med. Virol. 2020, 92, 2999-3006. [CrossRef]

2. Simões, E.A.F.; DeVincenzo, J.P.; Boeckh, M.; Bont, L.; Crowe, J.E.; Griffiths, P.; Hayden, F.G.; Hodinka, R.L.; Smyth, R.L.; Spencer, K.; et al. Challenges and opportunities in developing respiratory syncytial virus therapeutics. J. Infect. Dis. 2015, 211, S1-S20. [CrossRef]

3. World Health Organization. WHO Strategy to Pilot Global Respiratory Syncytial Virus Surveillance Based on the Global Influenza Surveillance and Response System (GISRS); World Health Organization: Geneva, Switzerland, 2017; Available online: https: / /apps.who.int/iris/handle/10665/259853 (accessed on 20 December 2020).

4. Shi, T.; McAllister, D.A.; O’Brien, K.L.; Simoes, E.A.F.; Madhi, S.A.; Gessner, B.D.; Polack, F.P.; Balsells, E.; Acacio, S.; Aguayo, C.; et al. Global, regional, and national disease burden estimates of acute lower respiratory infections due to respiratory syncytial virus in young children in 2015: A systematic review and modelling study. Lancet 2017, 390, 946-958. [CrossRef] 
5. Liu, L.; Oza, S.; Hogan, D.; Chu, Y.; Perin, J.; Zhu, J.; Lawn, J.E.; Cousens, S.; Mathers, C.; Black, R.E. Global, regional, and national causes of under-5 mortality in 2000-15: An updated systematic analysis with implications for the Sustainable Development Goals. Lancet 2016, 388, 3027-3035. [CrossRef]

6. Li, Y.; Reeves, R.M.; Wang, X.; Bassat, Q.; Brooks, W.A.; Cohen, C.; Moore, D.P.; Nunes, M.; Rath, B.; Campbell, H.; et al. Global patterns in monthly activity of influenza virus, respiratory syncytial virus, parainfluenza virus, and metapneumovirus: A systematic analysis. Lancet Glob. Health 2019, 7, e1031-e1045. [CrossRef]

7. Taylor, S.; Taylor, R.J.; Lustig, R.L.; Schuck-Paim, C.; Haguinet, F.; Webb, D.J.; Logie, J.; Matias, G.; Fleming, D.M. Modelling estimates of the burden of respiratory syncytial virus infection in children in the UK. BMJ Open 2016, 6, e009337. [CrossRef]

8. Zhao, Y.; Lu, R.; Shen, J.; Xie, Z.; Liu, G.; Tan, W. Comparison of viral and epidemiological profiles of hospitalized children with severe acute respiratory infection in Beijing and Shanghai, China. BMC Infect. Dis. 2019, 19, 729. [CrossRef]

9. Checchia, P.A.; Paes, B.; Bont, L.; Manzoni, P.; Simões, E.A.F.; Fauroux, B.; Figueras-Aloy, J.; Carbonell-Estrany, X. Defining the Risk and Associated Morbidity and Mortality of Severe Respiratory Syncytial Virus Infection Among Infants with Congenital Heart Disease. Infect. Dis. Ther. 2017, 6, 37-56. [CrossRef]

10. Paes, B.; Fauroux, B.; Figueras-Aloy, J.; Bont, L.; Checchia, P.A.; Simões, E.A.F.; Manzoni, P.; Carbonell-Estrany, X. Defining the Risk and Associated Morbidity and Mortality of Severe Respiratory Syncytial Virus Infection Among Infants with Chronic Lung Disease. Infect. Dis. Ther. 2016, 5, 453-471. [CrossRef] [PubMed]

11. Löwensteyn, Y.N.; Phijffer, E.W.E.M.; Simons, J.V.L.; Scheltema, N.M.; Mazur, N.I.; Nair, H.; Bont, L.J. Respiratory syncytial virus-related death in children with down syndrome: The RSV GOLD Study. Pediatr. Infect. Dis. J. 2020, 39, 665-670. [CrossRef] [PubMed]

12. Anderson, E.J.; Carosone-Link, P.; Yogev, R.; Yi, J.; Simões, E.A.F. Effectiveness of Palivizumab in High-risk Infants and Children: A Propensity Score Weighted Regression Analysis. Pediatr. Infect. Dis. J. 2017, 36, 699-704. [CrossRef]

13. Mazur, N.I.; Martinón-Torres, F.; Baraldi, E.; Fauroux, B.; Greenough, A.; Heikkinen, T.; Manzoni, P.; Mejias, A.; Nair, H.; Papadopoulos, N.G.; et al. Lower respiratory tract infection caused by respiratory syncytial virus: Current management and new therapeutics. Lancet Respir. Med. 2015, 3, 888-900. [CrossRef]

14. Higgins, D.; Trujillo, C.; Keech, C. Advances in RSV vaccine research and development-A global agenda. Vaccine 2016, 34, 2870-2875. [CrossRef] [PubMed]

15. Ventre, K.; Randolph, A. Ribavirin for respiratory syncytial virus infection of the lower respiratory tract in infants and young children. Cochrane Database Syst. Rev. 2010, 5, CD000181. [CrossRef]

16. Modjarrad, K.; Giersing, B.; Kaslow, D.C.; Smith, P.G.; Moorthy, V.S. WHO consultation on Respiratory Syncytial Virus Vaccine Development Report from a World Health Organization Meeting held on 23-24 March 2015. Vaccine 2016, 34, 190-197. [CrossRef] [PubMed]

17. Reeves, R.M.; Hardelid, P.; Panagiotopoulos, N.; Minaji, M.; Warburton, F.; Pebody, R. Burden of hospital admissions caused by respiratory syncytial virus (RSV) in infants in England: A data linkage modelling study. J. Infect. 2019, 78, 468-475. [CrossRef]

18. Tam, J.; Papenburg, J.; Fanella, S.; Asner, S.; Barton, M.; Bergeron, C.; Desai, S.; Hui, C.; Foo, C.; Langley, J.M.; et al. Pediatric investigators collaborative network on infections in Canada study of respiratory syncytial virus-associated deaths in pediatric patients in Canada, 2003-2013. Clin. Infect. Dis. 2019, 68, 113-119. [CrossRef] [PubMed]

19. Cai, W.; Buda, S.; Schuler, E.; Hirve, S.; Zhang, W.; Haas, W. Risk factors for hospitalized respiratory syncytial virus disease and its severe outcomes. Influenza Other Respir. Viruses 2020, 14, 658-670. [CrossRef]

20. Broberg, E.K.; Waris, M.; Johansen, K.; Snacken, R.; Penttinen, P.; Trebbien, R.; Emborg, H.D.; Krause, T.G.; Fischer, T.K.; Kuznetsova, N.; et al. Seasonality and geographical spread of respiratory syncytial virus epidemics in 15 european countries, 2010 to 2016. Eurosurveillance 2018, 23, 17-00284. [CrossRef] [PubMed]

21. Moher, D.; Shamseer, L.; Clarke, M.; Ghersi, D.; Liberati, A.; Petticrew, M.; Shekelle, P.; Stewart, L. Preferred reporting items for systematic review and meta-analysis protocols (PRISMA-P) 2015 statement. Syst. Rev. 2015, 4, 1. [CrossRef]

22. Howick, J.; Chalmers, I.; Glasziou, P.; Greenhalg, T.; Heneghan, C.; Liberati, A.; Moschetti, I.; Phillips, B.; Thornton, H. The Oxford 2011 Levels of Evidence. Available online: https:/ / www.cebm.net/2016/05/ocebm-levels-of-evidence (accessed on 5 December 2020).

23. Sanderson, S.; Tatt, I.D.; Higgins, J.P.T. Tools for assessing quality and susceptibility to bias in observational studies in epidemiology: A systematic review and annotated bibliography. Int. J. Epidemiol. 2007, 36, 666-676. [CrossRef] [PubMed]

24. Higgins, J.P.T.; Thompson, S.G.; Deeks, J.J.; Altman, D.G. Measuring inconsistency in meta-analyses. Br. Med. J. 2003, 327, 557-560. [CrossRef]

25. Amat, F.; Plantard, C.; Mulliez, A.; Petit, I.; Rochette, E.; Verdan, M.; Henquell, C.; Labbé, G.; Heraud, M.C.; Evrard, B.; et al. RSV-hRV co-infection is a risk factor for recurrent bronchial obstruction and early sensitization 3 years after bronchiolitis. J. Med. Virol. 2018, 90, 867-872. [CrossRef] [PubMed]

26. Atay, Ö.; Pekcan, S.; Göktürk, B.; Özdemir, M. Risk factors and clinical determinants in bronchiolitis of infancy. Turk. Thorac. J. 2020, 21, 156-162. [PubMed]

27. Barlotta, A.; Pirillo, P.; Stocchero, M.; Donato, F.; Giordano, G.; Bont, L.; Zanconato, S.; Carraro, S.; Baraldi, E. Metabolomic profiling of infants with recurrent wheezing after bronchiolitis. J. Infect. Dis. 2019, 219, 1216-1223. [CrossRef] [PubMed] 
28. Bekhof, J.; Wessels, M.; ten Velde, E.; Hoekstra, M.; Langenhorst, V.; Bruijnesteijn, L.; Brand, P.L.P.; Ruijs, G.J.H.M. Room Sharing in Hospitalized Children with Bronchiolitis and the Occurrence of Hospital-Acquired Infections: A Prospective Cohort Study. Hosp. Pediatr. 2019, 9, 415-422. [CrossRef]

29. Cangiano, G.; Nenna, R.; Frassanito, A.; Evangelisti, M.; Nicolai, A.; Scagnolari, C.; Pierangeli, A.; Antonelli, G.; Papoff, P.; Petrarca, L.; et al. Bronchiolitis: Analysis of 10 consecutive epidemic seasons. Pediatr. Pulmonol. 2016, 51, 1330-1335. [CrossRef] [PubMed]

30. Esposito, S.; Scarselli, E.; Lelii, M.; Scala, A.; Vitelli, A.; Capone, S.; Fornili, M.; Biganzoli, E.; Orenti, A.; Nicosia, A.; et al. Antibody response to respiratory syncytial virus infection in children $<18$ months old. Hum. Vaccines Immunother. 2016, 12, 1700-1706.

31. Faber, T.E.; Schuurs, T.A.; Veeger, N.J.G.M.; Hennus, M.P.; Bont, L.J. Dynamics of nasopharyngeal pneumococcal carriage during the course of viral bronchiolitis. Pediatr. Pulmonol. 2016, 51, 863-867. [CrossRef] [PubMed]

32. Gökçe, Ş.; Kurugöl, Z.; Koturoğlu, G.; Çiçek, C.; Aslan, A. Etiology, Seasonality, and Clinical Features of Viral Respiratory Tract Infections in Children Hospitalized With Acute Bronchiolitis: A Single-Center Study. Glob. Pediatr. Health 2017, 4, 2333794X1771437. [CrossRef]

33. Karppinen, S.; Toivonen, L.; Schuez-Havupalo, L.; Waris, M.; Peltola, V. Interference between respiratory syncytial virus and rhinovirus in respiratory tract infections in children. Clin. Microbiol. Infect. 2016, 22, e1-e208. [CrossRef] [PubMed]

34. Korsun, N.; Angelova, S.; Trifonova, I.; Georgieva, I.; Voleva, S.; Tzotcheva, I.; Mileva, S.; Ivanov, I.; Tcherveniakova, T.; Perenovska, P. Viral pathogens associated with acute lower respiratory tract infections in children younger than 5 years of age in Bulgaria. Braz. J. Microbiol. 2019, 50, 117-125. [CrossRef] [PubMed]

35. Kutsaya, A.; Teros-Jaakkola, T.; Kakkola, L.; Toivonen, L.; Peltola, V.; Waris, M.; Julkunen, I. Prospective clinical and serological follow-up in early childhood reveals a high rate of subclinical RSV infection and a relatively high reinfection rate within the first 3 years of life. Epidemiol. Infect. 2016, 144, 1622-1633. [CrossRef] [PubMed]

36. Midulla, F.; Nenna, R.; Scagnolari, C.; Petrarca, L.; Frassanito, A.; Viscido, A.; Arima, S.; Antonelli, G.; Pierangeli, A. How Respiratory Syncytial Virus Genotypes Influence the Clinical Course in Infants Hospitalized for Bronchiolitis. J. Infect. Dis. 2019, 219, 526-534. [CrossRef] [PubMed]

37. Nenna, R.; Evangelisti, M.; Frassanito, A.; Scagnolari, C.; Pierangeli, A.; Antonelli, G.; Nicolai, A.; Arima, S.; Moretti, C.; Papoff, P.; et al. Respiratory syncytial virus bronchiolitis, weather conditions and air pollution in an Italian urban area: An observational study. Environ. Res. 2017, 158, 188-193. [CrossRef]

38. Petrarca, L.; Nenna, R.; Frassanito, A.; Pierangeli, A.; Leonardi, S.; Scagnolari, C.; Antonelli, G.; Papoff, P.; Moretti, C.; Midulla, F. Acute bronchiolitis: Influence of viral co-infection in infants hospitalized over 12 consecutive epidemic seasons. J. Med. Virol. 2018, 90, 631-638. [CrossRef]

39. Ramos-Fernández, J.M.; Moreno-Pérez, D.; Gutiérrez-Bedmar, M.; Hernández-Yuste, A.; Cordón-Martínez, A.M.; Milano-Manso, G.; Urda-Cardona, A. Predicción de la evolución de la bronquiolitis por virus respiratorio sincitial en lactantes menores de 6 meses. Rev. Esp. Salud Publica 2017, 91, 201701006.

40. Resch, B.; Wörner, C.; Özdemir, S.; Hubner, M.; Puchas, C.; Urlesberger, B. Respiratory Syncytial Virus Associated Hospitalizations in Infants of 33 to 42 Weeks' Gestation: Does Gestational Age Matter? Klin. Padiatr. 2019, 231, $206-211$.

41. Shmueli, E.; Berger, T.; Herman, Y.A.; Chodick, G.; Rom, E.; Bilavsky, E.; Ashkenazi-Hoffnung, L.; Ashkenazi, S.; Amir, J.; Prais, D. Real-life comparison of three general paediatric wards showed similar outcomes for children with bronchiolitis despite different treatment regimens. Acta Paediatr. Int. J. Paediatr. 2017, 106, 1507-1511. [CrossRef]

42. Toivonen, L.; Karppinen, S.; Schuez-Havupalo, L.; Teros-Jaakkola, T.; Mertsola, J.; Waris, M.; Peltola, V. Respiratory syncytial virus infections in children 0-24 months of age in the community. J. Infect. 2020, 80, 69-75. [CrossRef]

43. Van de Steen, O.; Miri, F.; Gunjaca, M.; Klepac, V.; Gross, B.; Notario, G.; Wegzyn, C.M. The Burden of Severe Respiratory Syncytial Virus Disease Among Children Younger than 1 Year in Central and Eastern Europe. Infect. Dis. Ther. 2016, 5, 125-137. [CrossRef]

44. Wishaupt, J.; Van Den Berg, E.; Van Wijk, T.; Van Der Ploeg, T.; Versteegh, F.; Hartwig, N. Paediatric apnoeas are not related to a specific respiratory virus, and parental reports predict hospitalisation. Acta Paediatr. Int. J. Paediatr. 2016, 105, 542-548. [CrossRef] [PubMed]

45. Bardach, A.; Rey-Ares, L.; Cafferata, M.L.; Cormick, G.; Romano, M.; Ruvinsky, S.; Savy, V. Systematic review and meta-analysis of respiratory syncytial virus infection epidemiology in Latin America. Rev. Med. Virol. 2014, 24, 76-89. [CrossRef] [PubMed]

46. Kenmoe, S.; Bigna, J.J.; Well, E.A.; Simo, F.B.N.; Penlap, V.B.; Vabret, A.; Njouom, R. Prevalence of human respiratory syncytial virus infection in people with acute respiratory tract infections in Africa: A systematic review and meta-analysis. Influenza Other Respi. Viruses 2018, 12, 793-803. [CrossRef] [PubMed]

47. Zhang, Y.; Yuan, L.; Zhang, Y.; Zhang, X.; Zheng, M.; Kyaw, M.H. Burden of respiratory syncytial virus infections in China: Systematic review and meta-analysis. J. Glob. Health 2015, 5, 020417. [CrossRef]

48. Gaymard, A.; Bouscambert-Duchamp, M.; Pichon, M.; Frobert, E.; Vallee, J.; Lina, B.; Casalegno, J.S.; Morfin, F. Genetic characterization of respiratory syncytial virus highlights a new BA genotype and emergence of the ON1 genotype in Lyon, France, between 2010 and 2014. J. Clin. Virol. 2018, 102, 12-18. [CrossRef]

49. Hasegawa, K.; Linnemann, R.W.; Avadhanula, V.; Mansbach, J.M.; Piedra, P.A.; Gern, J.E.; Camargo, C.A. Detection of respiratory syncytial virus and rhinovirus in healthy infants. BMC Res. Notes 2015, 8, 718. [CrossRef] [PubMed] 
50. Hirve, S.; Crawford, N.; Palekar, R.; Zhang, W.; Bancej, C.; Barr, I.; Baumeister, E.; Broor, S.; Burmaa, A.; Campbell, H.; et al. Clinical characteristics, predictors, and performance of case definition-Interim results from the WHO global respiratory syncytial virus surveillance pilot. Influenza Other Respir. Viruses 2019, 14, 647-657. [CrossRef]

51. Güllü, E.İ; Akın, Y.; Karaaslan, A.; Vayvada, E.R.; Atabek, A.A.; Narter, F.K. RSV infection in Istanbul: Risk factors and frequency. J. Infect. Dev. Ctries 2017, 11, 691-696. [CrossRef]

52. Amini, R.; Gilca, R.; Boucher, F.D.; Charest, H.; De Serres, G. Respiratory syncytial virus contributes to more severe respiratory morbidity than influenza in children $<2$ years during seasonal influenza peaks. Infection 2019, 47, 595-601. [CrossRef]

53. Cattoir, L.; Vankeerberghen, A.; Boel, A.; Van Vaerenbergh, K.; De Beenhouwer, H. Epidemiology of RSV and hMPV in Belgium: A 10-year follow-up. Acta Clin. Belg. Int. J. Clin. Lab. Med. 2019, 74, 229-235. [CrossRef] [PubMed]

54. Yassine, H.M.; Sohail, M.U.; Younes, N.; Nasrallah, G.K. Systematic review of the respiratory syncytial virus (RSV) prevalence, genotype distribution, and seasonality in children from the middle east and North Africa (MENA) region. Microorganisms 2020, 8 , 713. [CrossRef] [PubMed]

55. Reeves, R.M.; van Wijhe, M.; Tong, S.; Lehtonen, T.; Stona, L.; Teirlinck, A.C.; Fernandez, L.V.; Li, Y.; Giaquinto, C.; Fischer, T.K.; et al. Respiratory Syncytial Virus-Associated Hospital Admissions in Children Younger Than 5 Years in 7 European Countries Using Routinely Collected Datasets. J. Infect. Dis. 2020, 222, S599-S605. [CrossRef]

56. Tsou, P.; Vadivelan, A.; Kovvuri, M.; Garg, N.; Thangavelu, M.; Wang, Y.; Raj, S. Association between multiple respiratory viral infections and pediatric intensive care unit admission among infants with bronchiolitis. Arch. Pediatr. 2020, 27, 39-44. [CrossRef] [PubMed]

57. Oliveira-Santos, M.; Santos, J.A.; Soares, J.; Dias, A.; Quaresma, M. Influence of meteorological conditions on RSV infection in Portugal. Int. J. Biometeorol. 2016, 60, 1807-1817. [CrossRef]

58. Relić, T.; Ilić, N.; Kostić, G.; Jovanović, D.; Tambur, Z.; Lazarević, I. Respiratory syncytial virus infection and bronchial hyperreactivity in children up to two years of age in correlation with atopy. Vojnosanit. Pregl. 2016, 73, 59-65. [CrossRef]

59. Jepsen, M.T.; Trebbien, R.; Emborg, H.D.; Krause, T.G.; Schønning, K.; Voldstedlund, M.; Nielsen, J.; Fischer, T.K. Incidence and seasonality of respiratory syncytial virus hospitalisations in young children in Denmark, 2010 to 2015. Eurosurveillance 2018, 23, 17-00163. [CrossRef]

60. Kramer, R.; Duclos, A.; Lina, B.; Casalegno, J.S. Cost and burden of RSV related hospitalisation from 2012 to 2017 in the first year of life in Lyon, France. Vaccine 2018, 36, 6591-6593. [CrossRef]

61. Vandini, S.; Bottau, P.; Faldella, G.; Lanari, M. Immunological, viral, environmental, and individual factors modulating lung immune response to respiratory syncytial virus. Biomed Res. Int. 2015, 2015. [CrossRef]

62. Nicolai, A.; Frassanito, A.; Nenna, R.; Cangiano, G.; Petrarca, L.; Papoff, P.; Pierangeli, A.; Scagnolari, C.; Moretti, C.; Midulla, F. Risk factors for virus-induced acute respiratory tract infections in children younger than 3 years and recurrent wheezing at 36 months follow-up after discharge. Pediatr. Infect. Dis. J. 2017, 36, 179-183. [CrossRef]

63. Feldman, A.S.; He, Y.; Moore, M.L.; Hershenson, M.B.; Hartert, T.V. Toward primary prevention of asthma: Reviewing the evidence for early-life respiratory viral infections as modifiable risk factors to prevent childhood asthma. Am. J. Respir. Crit. Care Med. 2015, 191, 34-44. [CrossRef] [PubMed]

64. Wildenbeest, J.G.; Zuurbier, R.P.; Korsten, K.; van Houten, M.A.; Billard, M.N.; Derksen-Lazet, N.; Snape, M.D.; Drysdale, S.B.; Robinson, H.; Pollard, A.J.; et al. Respiratory Syncytial Virus Consortium in Europe (RESCEU) Birth Cohort Study: Defining the Burden of Infant Respiratory Syncytial Virus Disease in Europe. J. Infect. Dis. 2020, 222, S606-S612. [CrossRef] [PubMed] 